\title{
Bernharda Schmida (1872-1947) zasługi dla ziemi chełmińskiej
}

\section{Stan badań i cel artykułu}

W stosunkowo bogatej już polskiej i niemieckiej literaturze poświęconej Bernhardowi Schmidowi ${ }^{1}$, wybitnej postaci niemieckiego konserwatorstwa pierwszej połowy XX wieku, wciąż brakuje opracowania o jego różnorodnej działalności na terenie dawnych południowych Prus Zachodnich. Lepiej rozpoznane są jedynie związki rodzinne i jego zaangażowanie w ochronę zabytków Grudziądza do 1918 roku, wówczas czwartego co do wielkości miasta w tej części Prus ${ }^{2}$. Krótkie uwagi na temat jego działalności w tej prowin-

\footnotetext{
1 Literaturę i źródła do życia i działalności Bernharda Schmida zebrał i omówil: Wiesław SIERADZAN, Bernhard Schmid (1872-1947). Księgozbiór prywatny ostatniego niemieckiego konserwatora zabytków w Malborku, Malbork 2011, s. 11-18; TENżE, Bernhard Schmid (1872-1947) jako członek kościoła unijnego $w$ świetle referatu wygłoszonego na synodzie intendentury malborskiej w 1929/1930, „Gdański Rocznik Ewangelicki”, 5, 2011, s. 118-155; TENŻE, Historia i znaczenie zbiorów Biblioteki Katedry Filologii Germańskiej Uniwersytetu Mikołaja Kopernika w Toruniu - depozyt w Bibliotece Uniwersyteckiej w Toruniu, „Folia Toruniensia”, 14, 2014, s. 41-62; TENżE, Czy Bernhard Schmid (1872-1947), ostatni niemiecki konserwator zamku malborskiego, był nazistą?, „Komunikaty Mazursko-Warmińskie”, 284, 2014, nr 2, s. 251-271; TENŻE, Uzupetnienia do rekonstrukcji księgozbioru Bernharda Schmida, [w:] Księgozbiory rozproszone. Losy księgozbiorów historycznych po II wojnie światowej, red. Aleksandra SiUciak, Malbork 2014, s. $189-206$.

2 Wiesław Sieradzan, Związi ostatniego konserwatora zabytków Prus Zachodnich Bernharda Schmida (1872-1947) i jego rodziny z Grudziądzem, „Rocznik Grudziądzki”, 20, 2012, s. 203-222.
} 
cji czynione przy okazji publikowania kolejnych biogramów ${ }^{3}$ przez polskich i niemieckich historyków i historyków sztuki w żaden sposób nie mogą być uznane za wystarczające. Znacznie lepiej wypada ocenić naszą wiedzę o działalności Bernharda Schmida w samym Malborku, ale bardziej na zamku, niż w mieście ${ }^{4}$. Mamy już też orientację $w$ bogatym i interdyscyplinarnym warsztacie naukowo-konserwatorskim ostatniego konserwatora prowincji Prusy Zachodnie ${ }^{5}$.

Artykuł jest próbą odpowiedzi na pytanie, czy obecny region kujawsko-pomorski, a zwłaszcza ziemia chełmińska, był ważnym obszarem w działalności naukowo-konserwatorskiej Bernharda Schmida w Malborku, a jeżeli tak, to w czym wyrażały się jego zasługi dla tego rejonu i jego wkład w inwentaryzację zabytków, nadzór konserwatorski oraz wykonawstwo.

\section{Postać i działalność Bernharda Schmida \\ - ujęcie syntetyczne. Związki rodzinne z południową częścią Prus Zachodnich}

Urodzony w 1872 roku w Bernburgu nad Soławą w Saksonii Anhaldzkiej Bernhard Ernst Gustav Schmid pojawił się na terenie Prus Zachodnich, a dokładnie w Malborku, w roku 1897, po ukończeniu studiów w Wyższej Szkole Technicznej w Berlinie (Technische Hochschule Charlottenburg) i po krótkim okresie zatrudnienia na stanowisku rejencyjnego technika budowlanego w Koblencji ${ }^{6}$. Jego pozycja zawodowa początkowo nie była ustabilizowana. W pierwszym okresie został pomocnikiem Conrada Steinbrechta przy pracach na zamku rozpoczętych na początku 1900 roku, co miało trwać półtora roku.

3 Erich Keyser, Bernhard Schmid (1872-1947), "Zeitschrift für Ostforschung”, 1, 1952, H. 4, s. 539-542; Rainer Zacharias, Schmid Bernhard Ernst Gustav, Architekt, preußischer Landeskonservator und Baumeister der Marienburg, [w:] Altpreußische Biographie, 5, Marburg/Lahn 2007, s. 1934-1935; Marian Arszyński, Schmid Bernhard, [w:] Polski słownik biograficzny konserwatorów zabytków, z. 2, Poznań 2006, s. 229-231.

4 Artur Dobry, Die denkmalpflegerische Tätigkeit Bernhard Schmids auf der Marienburg, [w:] Kunsthistoriker und Denkmalpfleger des Ostens. Der Beitrag zur Entwicklung des Faches im 19. und 20. Jahrhundert, Hg. Gerhard EIMER, Ernst GIERLICH, („Kunsthistorische Arbeiten der Kulturstiftung der deutschen Vertriebenen" 5), Bonn 2007, s. 111-117.

5 Wiesław Sieradzan, Die Werkstatt des deutschen Denkmalpflegers Bernhard Schmids (1872-1947) in Marienburg, [w:] Mobilität und regionale Vernetzung zwischen Oder und Memel: eine europäische Landschaft neu zusammensetzen, Hg. Olga KuRILO, Berlin 2011, s. 195-208.

6 Od tego roku Bernhard Schmid nieprzerwanie, aż do końca stycznia 1945 r., mieszkał w Malborku, najpierw przy ul. Mühlengasse 19 (obecna ul. Żeromskiego), później na Przedzamczu, pod ówczesnym adresem Friedrichplatz 4. Pierwszą wycieczkę do Malborka Schmid odbył jeszcze podczas nauki w gimnazjum w Kołobrzegu ok. 1890 r., Muzeum Zamkowe w Malborku, 556, k. 35-38. 
Dzięki wsparciu konserwatora zamku udało się to zatrudnienie przedłużyć ${ }^{7}$. W 1899 roku, wygrywając konkurs, zająl się odbudową spalonego gotyckiego ratusza malborskiego. Po pierwszym sukcesie konserwatorskim, debiucie naukowym w postaci skromnej pracy o tablicy trumiennej (Sargeschild) w kościele w Zajezierzu (Seergertswalde, obecnie w powiecie ostródzkim, dawniej pow. Morąg) w 1900 roku $^{8}$ oraz po opublikowaniu w 1902 roku sprawozdania (Das Rathaus in Marienburg in Westpreußen) ze swojej pierwszej samodzielnej pracy99, w dniu 1 stycznia 1903 roku, w młodym wieku - zaledwie 31 lat, Bernhard Schmid objął funkcję konserwatora zabytków Prus Zachodnich z miejscem przebywania w Malborku' ${ }^{10}$. Od 1912 aż do 1925 roku łączył tę funkcję ze stanowiskiem kierownika Powiatowego Urzędu Budowlanego z tytułem Baurat ${ }^{11}$.

Jednym z głównych zadań Bernharda Schmida jako konserwatora prowincji była kontynuacja inwentaryzowania zabytków Prus Zachodnich, wielkiego dzieła Johannesa Heisego rozpoczętego w 1871 roku. Na początku zajął się również sprawą przeniesienia tego urzędu ze Starogardu Gdańskiego do Malborka, co udało się sfinalizować w roku 1905. Był to w rzeczywistości niezbyt ważny urząd ze skromnym uposażeniem. Pełnił go jednak sumiennie aż do 1941 roku, kiedy, wbrew swej woli, musiał z niego zrezygnować ${ }^{12}$.

Pomimo urodzenia w odległej Saksonii Anhaldzkiej, rodzina Schmidów miała korzenie pomorsko-pruskie. Na podstawie archiwum rodzinnego, korespondencji z przedstawicielami rodu oraz z różnymi instytucjami, konserwatorowi pruskiemu udało się ustalić jej drzewo genealogiczne od pierwszej połowy XVII wieku. Ród Schmidów był przede wszystkim związany z Prusami (Królewiec) i Pomorzem (Usedom, Gryfice). Sporadycznie można znaleźć wśród przodków osoby z nazwiskami polskimi ${ }^{13}$.

7 Herder Institut Marburg, Dokumentensammlung (dalej cyt.: HIM, DS), 100_Schmid_7_022, s. 22.

8 Bernhard Schmid, Sargschild eines Meyer von Büren in der Kirche zu Seegertswalde (Ostpr.), „Deutsche Herold”, 31, 1900, s. 112.

9 Bernhard Schmid, Das Rathaus in Marienburg in Westpreußen, "Die Denkmalpflege”, 4, 1902, Nr. 11, s. 81-88; Wiesław Sieradzan, Poczqtki warsztatu naukowo-konserwatorskiego Bernharda Schmida (1872-1947). Uwagi na marginesie albumu „Rathaus in Marienburg”, [w:] W stużbie zabytków, red. Janusz HochleItNeR i Karol PolEjowski, Malbork 2017, s. 217-230.

10 Sieradzan 2011, s. 23. Decyzja o objęciu stanowiska konserwatora prowincji zachodniopruskiej zapadła już 8 XII 1902 r. HIM, DS, 100_Schmid_7_022, s. 22.

11 Rainer Zacharias, Bernhard Schmid (1872-1947). Preußischer Landeskonservator und Baumeister der Marienburg, [w:] Das Preußenland als Forschungsaufgabe. Eine europäische Region in ihren geschichtlichen Bezügen. Festschrift für Udo Arnold zum 60. Geburtstag gewidmet von den Mitgliedern der Historischen Kommission für ost- und westpreußische Landesforschung, Hg. Bernhart JëHNIG, Georg Michels, Lüneburg 2000, s. 693.

12 HIM, DS, 100_Schmid_2; Zacharias 2000, s. 693.

13 HIM, DS, 100_Schmid_6, 10v. 
Jego ojcem był Friedrich Wilhelm Gustaw Schmid urodzony 13 kwietnia 1826 roku w Festung Courbieré w Grudziądzu (zm. 16 lutego 1922). Początkowo Friedrich Wilhelm Gustaw zapisał się na studia. Jesienią 1845 roku immatrykulował się na uniwersytecie w Berlinie na filozofii, prawie i kameralistyce. Jednak już po roku porzucił uczelnię i wstąpił do wojska. Z racji wykonywanej profesji często przemieszczał się do licznych garnizonów pruskich. W latach 1846-1867 służył w 4. Wschodniopruskim Regimencie Grenadierów. Jako żołnierz zawodowy doszedł do stopnia majora. Matką Bernharda była Anna Ida Ernestine Julie von der Oelsnitz (1852-1918). Rodzice pobrali się w Chełmnie dnia 14 grudnia 1871 roku$^{14}$. Związki Schmidów z Prusami były jeszcze dłuższe. Warto wspomnieć o Auguście Schmid, który był najpierw (1795-1805) kwatermistrzem i audytorem w batalionie fizylierów w Piotrkowie, a później właścicielem majątku Krusin w ziemi chełmińskiej (gmina Lisewo). Zmarł w Grudziądzu 3 października 1815 roku. Jego syn - Christian August Emil - urodził się w Krusinie ${ }^{15} 16$ października 1808 roku, a ochrzczony został przez ewangelickiego kapelana w Grudziądzu 16 października roku 1810. Ten asesor królewski zmarł w Bydgoszczy 13 maja 1839 roku. Jego młodszym bratem był Friedrich Ludwig Schmid urodzony 7 listopada 1779 roku w Angermünde - pruski oficer-inżynier, który w latach 1828-1842, najpierw w randze kapitana, a później majora, służył w twierdzy Grudziądz. Na początku tego okresu mieszkała z nim również jego matka, wdowa po Johannie Zachariasie Schmid - Charlotte Sophie Elisabeth z domu von Pfeil. Wkrótce jednak, 9 czerwca 1828 roku, zmarła w twierdzy grudziądzkiej ${ }^{16}$.

Jak wynika z opublikowanego drukiem w gdańskiej oficynie A.W. Kafemanna dzieła Bernharda Schmida Stammtafel meiner Familie, Ludwig Schmid ożenił się z Henriettą Friedericke z domu Prange (urodzona 7 stycznia 1808 roku w Pawłowie [Paulsdorf] w powiecie kwidzyńskim, zmarła 19 maja 1905 roku w Grudziądzu ${ }^{17}$ ). Od 1843 roku był właścicielem domu przy ówczesnej ulicy Marienwerderstraße $27^{18}$, który szczęśliwie, po pewnej przebudowie, istnieje do dziś. Dziadek Bernharda Schmida zmarł na cholerę w Grudziądzu dnia 9 listopada 1848 roku. Wdowa Henriette Friedericke Schmid dnia 15 stycznia 1850 roku sprzedała parcelę i wyprowadziła się do Torunia, gdzie posiadała mieszkanie przy ówczesnej ulicy Elisabethstraße (obecnie Królowej Jadwigi) 85-86. Powróciła jednak do Grudziądza w 1870 roku i mieszkała ponow-

\footnotetext{
14 Erich Volmar, Danzig - In memoriam Bernhard Schmid, „Westpreußen Jahrbuch”, 1, 1950, s. 34 .

15 Sieradzan 2012, s. 213 (błędna pisownia wsi Krusin jako: Kruszyn).

16 TAMŻE, s. 213.

17 Bernhard Schmid, Stammtafel meiner Familie, Kolberg 1914 (HIM, DS, 100_Schmid_6, 9v).

18 HIM, DS, 100_Schmid_6, s. 65.
} 
nie przy ul. Marienwerderstraße - ale pod numerem $22^{19}$ - z krótką przerwą w latach 1879-1880, aż do śmierci. Początkowo w domu przy Marienwerderstraße 27 zamieszkiwała również ich córka, ciotka Bernharda Schmida, Henriette Franziska Emma Schmid. Urodziła się ona również w twierdzy grudziądzkiej 27 marca 1829 roku; zmarła w Grudziądzu, jako panna, 26 stycznia roku 1906. Ludwig Schmid został pochowany na cmentarzu fortecznym. Jego grób został zlikwidowany dopiero w 1941 roku, w momencie przygotowywania miejsca dla nowych pochówków, których w ostatnich latach wojny w szybkim tempie przybywało.

Na podstawie wyżej wymienionej pracy genealogicznej Bernharda Schmida można wskazać również na stare związki jego rodziny z Toruniem. Chodzi szczególnie o ojca Ludwiga Schmida - Johanna Zachariasa, notariusza publicznego, który w latach 1795-1806 był nadburmistrzem Torunia. Zmarł w tym mieście 3 października 1816 roku $^{20}$. Ponadto jego syn, starszy brat Ludwiga Schmida, wspomniany Johann Gotlieb August Schmid, powtórnie ożenił się 1 września 1805 roku z Christiną Elisabeth John, córką kupca, ławnika Starego Miasta, Johanna Thomasa Johna i Christiny Dorotei z domu Kerstein, urodzonej w 1781 roku, i zmarłej w tym mieście w 1851 roku $^{21}$.

\section{Publikacje o regionie}

Głównym zadaniem naukowym Bernharda Schmida po objęciu stanowiska konserwatora zabytków Prowincji Prusy Zachodnie było kontynuowanie dzieła zapoczątkowanego jeszcze w latach 80. XIX wieku przez Johannesa Heisego (1850-1899). Ten przedwcześnie zmarły (15 czerwca 1899 roku), najpierw inspektor budowlany prowincji Prusy Zachodnie, a od 27 lutego 1892 roku konserwator zabytków tej prowincji (nota bene zabiegający o utworzenie tego urzędu), zdążył przed śmiercią opublikować w monumentalnej serii Bau- und Kunstdenkmäler der Provinz Westpreußen, którą zapoczątkował na zamówienie prowincjonalnego Landtagu, katalogi zabytków dla powiatów kartuskiego, kościerskiego, starogardzkiego, toruńskiego, lubawskiego, gdańskiego i grudziądzkiego ${ }^{22}$. Bernhardowi Schmidowi w tym zakresie niewiele pozostawało do zrobienia poza terenem Powiśla. Już w 1906 roku opublikował 12. zeszyt wy-

19 TAMŻE, s. 66.

20 HIM, DS, 100_Schmid_6, 9v.

21 TAmżE. W Starym Mieście Toruniu w dniu 29 XI 1800 r. urodziła się ponadto inna krewna Schmida - Carolina Elisa Augusta Schmid, córka Johanna Carla Schmida (1775-1811), który sprawował urząd królewskiego komisarza sądowego w Toruniu, Płocku i Elblągu.

22 Johannes HeIse, Die Bau-und Kunstdenkmäler der Provinz Westpreußen, 1-11, Danzig $1884-1898$. 
dawnictwa, poświęcony zabytkom w powiecie suskim, w 1909 roku - w powiecie sztumskim (z. 13) a w 1919 roku - w części powiatu malborskiego (Nowy Staw i Nowy Dwór) ${ }^{23}$. Publikacji dalszych zeszytów przeszkodziły nie tylko trudne czasy, jakie nastały dla ochrony zabytków w Prusach Wschodnich po pierwszej wojnie światowej, ale przede wszystkim coraz liczniejsze, inne obowiązki i zainteresowania konserwatora zamku malborskiego, zwłaszcza po przejściu w 1922 roku na emeryturę Conrada Steinbrechta i przejęciu przez Schmida jego obowiązków na zamku.

W dorobku naukowym Benharda Schmida, obejmującym około 250 pozycji związanych bezpośrednio z historią sztuki, konserwacją zabytków oraz szeroko rozumianą przeszłością Prus Wschodnich i Zachodnich, są liczne prace o architekturze budowli nie tylko ceglanych, ale również z kamienia i drewna. Te ostatnie odnoszą się do budownictwa wiejskiego z terenu Niziny Toruńskiej ${ }^{24}$. Szczególnie wiele miejsca poświęcił zagadnieniom historii i restauracji zabytków Torunia, w tym: nastawie ołtarza głównego w kościele NMP ${ }^{25}$, rzeźbionemu krucyfiksowi z kościoła świętojańskiego ${ }^{26}$ oraz ołtarzowi św. Wolfganga $^{27}$, a z kościoła św. Jakuba - nagrobkom, sklepieniom oraz malowidłom ściennym ${ }^{28}$. Jeszcze przed pierwszą wojną światową opublikował w „Mitteilungen des Coppernicus-Vereins” artykuły dotyczące kamienicy przy Starym Rynku 22, sklepień i malowideł ściennych w kościele św. Jakuba oraz rzeźb goty-

23 Bernhard Schmid, Die Bau- und Kunstdenkmäler der Provinz Westpreußen, 12-13, Danzig 1906-1909; TENżE, Die Bau- und Kunstdenkmäler des Kreises Marienburg, 4: Die Städte Neuteich und Tiegenhof, Danzig 1919. W tym ostatnim przypadku Schmid dokonał radykalnej przebudowy wypracowanej wcześniej koncepcji tej wartościowej do dziś edycji.

24 Bernhard ScHмID, Über ältere Bauerhäuser in der Thorner Niederung, „Mitteilungen des Coppernicus-Vereins”, 14, 1906, s. 51-53. Zob. ponadto: TEnżE, Westpreußische Holzbauten, „Mitteilungen des Westpreußischen Geschichts-Vereins", 3, 1904, s. 22-27; TENŻE, Die Schurzholzkirchen Westpreußens, [w:] TEgoż, Die Denkmalpflege in der Provinz Westpreußen im Jahre 1905. 3. Bericht an die Provinzialkommission zur Verwaltung der Westpreußen Provinzialmuseen zu Danzig, Danzig 1907, s. 12-14; TENŻE, Die Holztürme und Fachwerkskirchen Westpreußens, [w:] TEgoż, Die Denkmalpflege in der Provinz Westpreußen im Jahre 1906. 4. Bericht an die Provinzialkommission zur Verwaltung der Westpreußen Provinzialmuseen zu Danzig, erstattet von Provinzialkonservator, Danzig 1907, s. 15-19.

25 Bernhard ScHMID, Der alte Hochaltar in St. Marien (Thorn), „Mitteilungen des Coppernicus-Vereins", 15, 1907, s. 40-42.

26 Bernhard ScHMID, Das Kreuzigungs-Bild in der Johanniskirche zu Thorn, „Mitteilungen des Coppernicus-Vereins", 16, 1908, s. 48-51.

${ }_{27}$ Bernhard ScHMID, Thorn. Instandsetzung des St. Wolfgangs-Altares in der Johanniskirche, [w:] TEgoż, Die Denkmalpflege in der Provinz Westpreußen im Jahre 1911. 9. Bericht an die Provinzialkommission zur Verwaltung der Westpreußen Provinzialmuseen zu Danzig, erstattet von Provinzialkonservator, Danzig 1912, s. 18-20.

28 Bernhard ScHMID, Die Grabsteine der Jakobskirche (Thorn), „Mitteilungen des Coppernicus-Vereins", 19, 1911, s. 47-59; TENŻE, Gotische Gewölbe-und Wandmalereien in der Jacobskirche (Thorn), TAMŻE, s. 76-79 oraz 20, 1912, s. 68. 
ckich w toruńskiej farze. Z okresu pierwszej wojny światowej pochodzi wiele prac dotyczących historii dzwonów w Prusach Zachodnich ${ }^{29}$. Schmid stał się wówczas ekspertem w tym zakresie, dzięki czemu był w stanie ochronić przed przetopieniem na armaty najcenniejsze obiekty. Podobnie było podczas drugiej wojny światowej.

Niewątpliwie wielkim rozczarowaniem było dla niemieckiego patrioty i konserwatysty oderwanie Prus Zachodnich od Niemiec po zakończeniu pierwszej wojny światowej. Miał nadzieję, że polskie służby konserwatorskie będą w stanie zapewnić zabytkom opiekę konserwatorską. Pisak: „Wir können nur den Wunsch aussprechen, daß unser Nachbarstaat sich in gleicher Weise der Denkmalpflege widmen möge, wie Preußen es tat und es für den deutschbleibenden Teil Westpreußens auch ferner tun wird"30.

Jedną z zasług Bernharda Schmida dla Grudziądza oraz południowej części Prus Zachodnich było aktywne współuczestniczenie w procesie nabycia, zabezpieczenia i konserwacji Poliptyku Grudziądzkiego. To jedno z najwspanialszych świadectw fundacji artystycznych zakonu krzyżackiego w Prusach, powstałe według różnych ustaleń, pomiędzy 1370/1380 a około 1400 rokiem, zostało rozpropagowane i ocalone w dużej mierze dzięki zaangażowaniu Schmi$\mathrm{da}^{31}$. W tym miejscu należy przypomnieć, że retabulum grudziądzkie początkowo było związane z kościołem konwentualnym na zamku krzyżackim w Grudziądzu. Po likwidacji kaplicy w końcu XVIII wieku większość poliptyku trafiła do Muzeum Prowincjonalnego Prus Zachodnich w Gdańsku, a trzy tablice pozostały w Grudziądzu (w kościele św. Mikołaja i w kaplicy cmentarnej) ${ }^{32}$. W latach 1907 i 1912 sprowadzono wszystkie części Poliptyku do Malborka, wydatkując na ten cel 8000 marek. Następnie w latach 1912-1916 retabulum poddano konserwacji i scaleniu. Prace te wykonywał malarz malborski Andreas Wesolowski pod nadzorem Conrada Steinbrechta. Miejscem prezentacji Poliptyku była wówczas kaplica św. Wawrzyńca na Przedzamczu w Malborku. Rola Bernharda Schmida w tym przedsięwzięciu była bardzo istotna, gdyż sprowadzenie zabytku do zamku malborskiego wymagało jego zgody i nadzoru. Zajął się ponadto opracowaniem naukowym dzieła, a świadectwem tego jest publikacja przechowywana w bibliotece Collegium Humanisticum UMK w Toruniu, która jest osobistym egzemplarzem artykułu Die Beziehungen des Graudenzer Al-

29 Rainer Zacharias, Kriegsalltag 1942-1945. Aus den Tagebuchaufzeichnungen des Konservators der Marienburg Bernhard Schmid, „Westpreußen Jahrbuch”, 51, 2001, s. 89-90.

30 Cyt. za: Bernhard Schmid, Die Denkmalpflege in der Provinz Westpreußen im Jahre 1918-19. 16. Bericht an die Provinzialkommission zur Verwaltung der Westpreußen Provinzialmuseen zu Danzig, Danzig 1920, s. 3.

31 Sylwia Getka-Pesta, Stan badań nad Ottarzem Grudziq̨dzkim, „Rocznik Grudziądzki”, 20, 2012, s. 115-135.

32 TAMŻE, s. 120. 
tarwerkes der Marienburg zur altböhmischen Malerei ${ }^{33}$, przekazanym konserwatorowi prowincji za pośrednictwem Conrada Steinbrechta w lipcu 1918 roku przez Josepha Neuwirtha (1855-1934). Ten wybitny profesor uniwersytetu praskiego, historyk sztuki, znawca sztuki i architektury średniowiecznej, w przypisie pierwszym swojej pracy zaznaczył, że w oczekiwaniu na wyczerpujące opracowanie dotyczące zabytku zajmuje się tylko jego związkami ze sztuką czeską z okresu późnego średniowiecza. W następnych latach Bernhard Schmid opublikował dwie prace na ten temat, a samo dzieło stało się jedną z głównych atrakcji średniowiecznego malarstwa na zamku malborskim. Pierwszym opracowaniem był krótki artykuł poświęcony retabulum grudziądzkiemu w czasopiśmie „Ostdeutsche Monatshefte” w 1922 roku $^{34}$. Schmid przedstawił w nim nie tylko analizę artystyczną dzieła, ale też wskazał na wywodzącego się z Pragi, a czynnego w Grudziądzu, autora obrazów. Zwracał uwagę, że pomimo istnienia kilkudziesięciu kaplic zamków krzyżackich w Prusach, z ich wyposażenia do czasów jemu współczesnych ocalało jedynie retabulum grudziądzkie. Fotografie poliptyku do artykułu wykonał znany artysta-plastyk i fotograf malborski, Karl Kuhnd. Tematyka zabytku musiała być konserwatorowi malborskiemu bliska, skoro w 1925 roku poświęcił mu nieco miejsca w tzw. Geschäftsbericht über die Zeit vom 1. April bis 31. Dezember 1925, w którym przedstawił wykaz najstarszych średniowiecznych rzeźb i obrazów znajdujących się w tym okresie na zamku malborskim. Zreferował literaturę i źródła poświęcone retabulum, problem jego autorstwa i treść, omówił kolorystykę ${ }^{35}$. Dwa lata później w gdańskim czasopiśmie "Zeitschrift des Westpreußischen Geschichts-Vereins” ukazał się artykuł Schmida poświęcony zamkowi grudziądzkiemu ${ }^{36}$. Jego celem był opis zamku pod względem architektonicznym na podstawie licznych zachowanych, nowożytnych źródeł ikonograficznych. Warto podkreślić wykorzystanie przez Schmida polskiej lustracji z 1565 roku oraz reprodukowanie widoków i rzutów pionowych zamku grudziądzkiego.

W obliczu zbliżających się wojsk radzieckich do Prus Wschodnich w 1944 roku jednym z głównych zadań Bernharda Schmida stało się zabezpieczenie najcenniejszych eksponatów zamkowych poprzez ich ukrycie na terenie zamku lub

33 Sygn. P-595.

34 Bernhard Schmid, Der Graudenzer Altar in Marienburg, „Ostdeutsche Monatshefte”, 3, 1922, s. 9-13. Dla porównania Steinbrecht opublikował jedynie artykuł: Conrad STEINBREcHT, Flügel-Altar aus der ehemaligen Schloßkapelle zu Graudenz, zur Zeit in der Marienburg, St. Lorentz-Kapelle, [w:] Nachrichten der Königlichen Schloßbauverwaltung zu Marienburg Westpreußen. Über der Tätigkeit in den Baujahren 1912 bis 1916, Danzig 1916.

35 Bernhard SchMID, Verzeichnis älterer Werke der Malerei und Bildnerei in der Marienburg, [w:] Geschäftsbericht über die Zeit vom 1. April bis 31. Dezember 1925 (Verein für die Herstellung und Ausschmückung der Marienburg), s. 5-7.

36 Bernhard Schmid, Zur Baugeschichte der Ordens- und Bischofs-Schlößer in Preußen. 1. Graudenz, „Zeitschrift des Westpreußischen Geschichtsvereins”, 69, 1929, s. 55-68. 
wywiezienie w bezpieczniejsze miejsce. Poliptyk Grudziądzki, w porozumieniu z nowym konserwatorem Okręgu Gdańsk-Prusy Zachodnie Erichem Volmarem, konserwator zamku malborskiego polecił ukryć w betonowym bunkrze w południowo-zachodnim rogu kaplicy św. Wawrzyńca. W liście do pozostającego w Malborku niemieckiego księdza katolickiego Konrada Willego, pisanym pod koniec 1946 roku z Husum, Schmid wskazał, gdzie ukrył m.in. poliptyk. Według ostatnich ustaleń wydaje się, że nastąpiło to już po fakcie odkrycia zabytku przez oficera polskiego i przewiezienia go pod koniec 1946 roku do warszawskiego Muzeum Wojska Polskiego ${ }^{37}$. W stolicy dzieło trafiło ostatecznie do Muzeum Narodowego, gdzie poddano je konserwacji, następnie znalazło swoje miejsce w Galerii Sztuki Średniowiecznej, w której eksponowane jest do dziś.

\section{Prace konserwatorskie}

Na podstawie literatury oraz corocznych sprawozdań z działalności Schmida jako konserwatora zabytków prowincji Prusy Zachodnie można stwierdzić, że koncentrował się on na właściwym przeprowadzeniu prac przy konserwacji witraży w kościołach toruńskich - św. św. Janów (1907-1908), św. Jakuba (1913-1914) i NMP (1911), zajmował się też restauracją refektarza zamku bierzgłowskiego (1911) według projektu Conrada Steinbrechta. Warto dodać, że jest to najcenniejsza i najbardziej udana praca konserwatorska w obrębie zamku, gdyż pozostałe jego partie (poza kapitularzem), są w stylu neogotyckim, a fragment założenia dobudowano wręcz zaprzeczając „steinbrechtowskim” zasadom (żadnego ruchu innego, niż w kierunku historycznym). Poza restauracją ołtarza św. Wolfganga w kościele św. Jana Chrzciciela i św. Jana Ewangelisty w Toruniu (1911) i w toruńskim kościele NMP, nadzorował prace w kościele św. Katarzyny w Brodnicy (1911-1914) i w zamku w Świeciu nad Wisłą (1916). Był również konsultantem przy budowie wieży w kościele w Papowie Toruńskim. Celowo użyto tu sformułowania "nadzorował”, gdyż w swych sprawozdaniach wspomina wyraźnie, że jego udział w wielu tych realizacjach konserwatorskich ograniczał się do wydawania zgody, konsultacji projektu i nadzoru. Same prace konserwatorskie były prowadzone przez służby niższego szczebla - na poziomie miast, które posiadały własnych konserwatorów lub architektów (Toruń, Grudziądz, Chełmno). Daje się to dostrzec na lepiej zbadanym przez autora niniejszego artykułu przykładzie Grudziądza, gdzie Schmid zabiegał nawet o uzyskanie dofinansowania do kosztów podejmowanych robót ze środków prowincjonalnych. W Grudziądzu Schmid zajmował się spichlerzami nadwiślańskimi. Ponieważ 10 lipca 1903 roku pożar uszkodził pięć z nich, a budynki te -

37 Getka-Pesta 2012, s. 123-124. 
zbudowane na stoku wzgórza na wysokich murach oporowych - były bardzo charakterystycznym elementem panoramy miasta, należało przystąpić do ich odbudowy. Czterech właścicieli zdecydowało się samodzielnie odtworzyć strome dachy kryte dachówką. Piąty dom (zapewne Speicherstraße 21), należący do pani (Auguste) Gadziewski, otrzymał podobne zamknięcie. Na wniosek konserwatora pruski minister przyznał pomoc finansową na te prace ${ }^{38}$. Dzięki wydawanym drukiem rocznym sprawozdaniom z tych czynności udało się ustalić obecność Schmida przy pracach w Grudziądzu w latach 1902, 1910, 1912 i 1918/1919. Koncentrowały się one na Górze Zamkowej, przy niektórych spichlerzach ${ }^{39}$.

W 1902 roku, pod nadzorem Schmida, na Górze Zamkowej po wschodniej stronie wykonano tarasy według projektu miejskiego radcy budowlanego, Martina Witta. Jako blaty stołów koło wieży zamkowej wykorzystano płyty nagrobne $\mathrm{z}$ rozebranego w 1900 roku kościoła ewangelickiego, znajdującego się przy Rynku. Pochodziły one przeważnie z XVII i XVIII wieku i zostały po rozbiórce kościoła sprzedane osobom prywatnym. Dzięki zabiegom dyrektora gimnazjum, tajnego radcy dr. Siegfrieda Angera, możliwe było ich odkupienie i zabezpieczenie poprzez nadanie im nowej funkcji ${ }^{40}$.

Ponadto w 1910 roku dokonano restauracji wieży zamkowej (Klimek). Bezpośrednie kierownictwo nad pracami sprawował Miejski Urząd Budowlany w Grudziądzu. Naprawiono wówczas uszkodzony cokół wieży, który ucierpiał od wody; ok. $1 \mathrm{~m}$ nad i 1,5 m pod ziemią zostało wykonane przenicowanie. Zwietrzała korona muru, wykonana przy okazji wcześniejszej rozbiórki górnej części wieży, ucierpiała na skutek działania wilgoci i mrozu i zagrażała leżącym poniżej warstwom cegły. Mur został wyrównany i zabezpieczony razem z platformą wewnętrzną za pomocą warstwy topionego asfaltu. Woda opadowa spływa z platformy przez żeliwne rury spustowe zamontowane wewnątrz wieży, które zasilają fosę zamkową. Koszty 1250 marek pokryło miasto oraz właścicielka Góry Zamkowej ${ }^{41}$.

W 1912 roku dokonano restauracji i adaptacji sali grudziądzkiego ratusza. Pomieszczenie dotychczasowego muzeum miejskiego w ratuszu - dawny refektarz - zostało wyremontowane i przystosowane na potrzeby sali posiedzeń (dla muzeum zbudowano nowy gmach). Ściany wnętrza jeszcze w czasach użytkowania gmachu przez seminarium jezuickie otynkowano, więc ma-

38 Bernhard ScHMID, Bericht der Provinzialkommission zur Verwaltung der Westpreußischen Provinzialmuseen über ihre Tätigkeit und die Verwendung der ihr zur Verfügung gestellten Mitteln im Jahre 1903, Danzig 1904, s. 10 i n.

39 Sieradzan 2012, s. 220.

40 TAMŻE, s. 220-221.

41 Bernhard Schmid, Die Denkmalpflege in der Provinz Westpreußen im Jahre 1903, 1. Bericht am die Provinzial-Kommission zur Verwaltung der Westpreußischen Provinzial-Museen zu Danzig, Danzig 1903; TENżE, Die Denkmalpflege in der Provinz Westpreußen im Jahre 1910, 8. Bericht am die Provinzial-Kommission zur Verwaltung der Westpreußischen Provinzial-Museen zu Danzig, Danzig 1911, s. 17; Sieradzan 2012, s. 221. 
lowidła się nie zachowały (pozostały po nich jedynie ślady złoceń); wykonano zatem nową dekorację ornamentalną w kolorze czerwonym, pasującym do stropu. Całość została odsłonięta i odrestaurowana przez malarza Arthura Fahlberga. Wyposażenie dla nowej funkcji zostało wykonane współcześnie. Przebudową kierowali miejski radca budowlany dr inż. Richard Korn i rejencyjny mistrz budowlany, Wilhelm Fauth ${ }^{42}$.

W roku 1919 w kościele parafialnym pw. św. Mikołaja przeprowadzono remont dachu. Wiosną 1918 roku runął fragment gzymsu po południowej stronie obiektu (przyczyną było zniszczenie końcówek belek). Nieszczelna była też południowa część przekrycia, a obluzowane dachówki zagrażały przechodniom. W styczniu wyremontowano więźbę dachową i wymieniono pokrycie dachu po południowej stronie na dachówki typu mnich-mniszka (z firmy Falck). Na nowo wykonano około 120-metrowy gzyms. Kierownictwo sprawował rejencyjny mistrz budowlany Müller z Powiatowego Urzędu Budowlanego w Grudziądzu ${ }^{43}$.

Liczne obowiązki konserwatora stosunkowo rozległej prowincji (ok. 1900 roku na obszarze $25534 \mathrm{~km}^{2}$ żyło 1563652 osób) wymagały częstych podróży. Bernhard Schmid rzadko podawał liczbę odbytych rocznie wyjazdów, ale można przyjąć, że było ich wiele. Przykładowo w 1906 roku wyjeżdżał w celach służbowych 45 razy, korzystając z rozbudowanej już wówczas sieci kolejowejł4

\section{Denkmalarchiv}

Na potrzeby prac konserwatorskich, pojmowanych już wtedy w sposób interdyscyplinarny (to znaczy z wykorzystaniem źródeł archiwalnych, drukowanych, literatury historycznej z zakresu historii sztuki oraz kartografii), Bernhard Schmid zbudował przy swoim urzędzie archiwum zabytków (Denkmalarchiv). Była to realizacja szerszej, ogólnoniemieckiej inicjatywy tworzenia takich ośrodków, przy czym w Prusach Zachodnich Prowincjonalna Komisja Muzealna w Gdańsku wydała już stosunkowo wcześnie, bo 7 grudnia 1903 roku, decyzję o utworzeniu takiego rodzaju archiwum w Malborku. Do jej dyspozycji przeznaczono rocznie niezbyt dużą kwotę 500 marek. Początkowo Denkmalarchiv znajdował się w prywatnym mieszkaniu Schmida przy

42 Bernhard ScHMID, Bericht der Provinzialkommission zur Verwaltung der Westpreußischen Provinzialmuseen über ihre Tätigkeit und die Verwendung der ihr zur Verfügung gestellten Mitteln im Jahre 1912, Danzig 1913, s. 19.

43 Bernhard Schmid, Die Denkmalpflege in der Provinz Westpreußen in Jahren 1918/1919, 16. Bericht am die Provinzial-Kommission zur Verwaltung der Westpreußischen Provinzial-Museen zu Danzig, Danzig 1920, s. 9; Sieradzan 2012, s. 221.

44 Bernhard Schmid, Die Denkmalpflege in der Provinz Westpreußen im Jahre 1906, 4. Bericht am die Provinzial-Kommission zur Verwaltung der Westpreußischen Provinzial-Museen zu Danzig, Danzig 1907, s. 5. 
ul. Mühlengasse 19. Po przejściu Conrada Steinbrechta na emeryturę, Schmid zajął część służbowej willi (Dienstvilla), i urządził w niej swój gabinet, pomieszczenie archiwum zabytków i prywatne mieszkanie. Niestety nie udało się włączyć do zbiorów tego archiwum rysunków Johannesa Heisego, które przepadły. Dołączono jedynie należące do niego negatywy fotografii, notatki i druki. Pomimo niskiego budżetu od początku istnienia archiwum gromadzono w nim wszystkie materiały służące inwentaryzacji zabytków prowincji - spisy, protokoły - dotyczące m.in.: domów wiejskich, domów mieszczańskich, umocnień miejskich, kościołów drewnianych, wyposażenia kościołów, malarstwa i rzeźby średniowiecznej i nowożytnej. Wszystko to miało być uzupełnieniem źródeł, m.in. widoków, dostępnych w archiwach i bibliotekach miejskich. Archiwum budowano nie tylko poprzez zakupy, ale także dzięki darowiznom osób prywatnych i władz różnych szczebli. Były to często cenne książki, fotografie oraz rysunki. Wszystkie druki, rysunki oraz fotografie były podzielone według powiatów i umieszczone w teczkach i szufladach specjalnej szafy. Nie dysponujemy wiedzą na temat liczby zgromadzonych w Denkmalarchiv fotografii zabytków. Wiadomo jedynie, że do początku pierwszej wojny światowej przechowywano tam 1081 negatywów. W późniejszym okresie archiwum było systematycznie wzbogacane i służyło bieżącym potrzebom konserwatorskim i naukowym. Do końca drugiej wojny światowej miało ogromne znaczenie historyczne dla badań zabytków również południowej części Prus Zachodnich, a więc w dużej części obecnego terytorium województwa kujawsko-pomorskiego. Niestety, archiwum nie przetrwało. Mamy nieco wyobrażenia na temat jego zasobów (np. kartograficznego), ale pozostała część - w tym przede wszystkim negatywy fotografii - uległy rozproszeniu lub zniszczeniu. Na niedawno wydanym CD ze zbiorami fotograficznymi dawnego Urzędu Konserwatorskiego Zabytków w Królewcu, obejmującym ok. 8 tysięcy zdjęć, znalazła się niewielka liczba fotografii z tego archiwum, zdeponowanych po drugiej wojnie światowej w Instytucie Sztuki PAN ${ }^{45}$ (przy czym odnoszą się one do ziem włączonych do Trzeciej Rzeszy po 1939 r.) Od 1939 roku Bernhard Schmid podjął pogłębione podróże studyjne po okupowanych terenach Polski i Litwy. Problematyczne jest, czy kierowały nim jedynie pobudki naukowe, aby oddać w literaturze stan zabytków w sposób wolny od naleciałości ideologicznych. Był w Kraju Warty i na północnych terenach Generalnej Guberni, następnie objechał zamki na Litwie. Powziął ponadto podróże do Rypina oraz ziemi ciechanowskiej, badając wpływy architektury krzyżackiej na Mazowszu ${ }^{46}$. W czasopiśmie „Altpreußische Forschungen” w roku 1940 w dwóch częściach Schmid opublikował artykuł Architektonische Stu-

45 Prusy Wschodnie. Zbiory fotograficzne dawnego Urzędu Konserwatora Zabytków w Królewcu (Dokumentation einer historischen Provinz Ostpreußen. Die photographische Sammlung des Provinzialdenkmalamtes in Königsberg), Warszawa 2009.

46 Zacharias 2000, s. 699. 
dienfahrten durch ehemalige Polen. Tekst jest swego rodzaju inwentaryzacją zabytków z terenu Kujaw, ziemi dobrzyńskiej i północnego Mazowsza. Przybliża on niemieckiemu czytelnikowi średniowieczną architekturę tych ziem, ze szczególnym zaakcentowaniem wpływu sąsiedztwa krzyżacko-polsko-mazowieckiego na jej kształt. Brak w nim, tak powszechnej w publikacjach badaczy niemieckich $\mathrm{z}$ tego okresu, tendencji nazistowskich, ale niewątpliwie daje o sobie znać docenianie roli kulturotwórczej zakonu krzyżackiego i jego oddziaływanie na sąsiednie państwa. Warto jednak zaznaczyć, że opracowania te mogą być częściowym efektem już przedwojennej podróży konserwatora malborskiego na opisywane tereny. W 1933 roku Bernhard Schmid uczestniczył w Międzynarodowym Kongresie Historyków w Warszawie; ponadto w 1935 roku, w okresie poprawy stosunków polsko-niemieckich, odwiedził w celach naukowych Toruń, Włocławek, Płock, Warszawę, Czersk i Brześć Kujawski"

\section{Pozostawiony księgozbiór prywatny}

Bernhard Schmid już na przełomie XIX i XX wieku przystąpił do systematycznego kolekcjonowania książek, które wiązały się z jego zawodem, pełnioną funkcją w Malborku i jego szerokimi zainteresowaniami. U progu XX wieku gromadzony planowo księgozbión liczył 190 pozycjii". W willi służbowej na Przedzamczu (Friedrichplatz 4, ob. tzw. „Dom Steinbrechta”) znajdowała się jego stale powiększająca się biblioteka. Zbiór tworzyły przede wszystkim jego własne prace, a ponadto publikacje z zakresu historii sztuki i utwory poetyckie ${ }^{49}$. Precyzyjna odpowiedź, jak wielki był to księgozbiór, chyba nie będzie możliwa do ustalenia, ale i tak należał on do najcenniejszych w Malborku ${ }^{50}$. Na podstawie kwerendy i materiałów tworzących spuściznę Schmida można stwierdzić, że w ciągu swojej ponad pięćdziesięcioletniej pracy zawodowej w Malborku oraz w Prusach Zachodnich i Wschodnich zgromadził niewątpliwie znaczącą - zarówno jeśli chodzi o ilość, jak i wartość naukową - prywatną kolekcję. Krótko przed śmiercią sam o nim napisał: „Sie ist das Ergebnis einer planmäßigen, 50-jährigen Sammelarbeit"51. W wyniku kwerendy w bibliotekach Gdańska, Malborka, Torunia, Olsztyna i Warszawy oraz w księgozbiorach prywatnych udało się odnaleźć do roku 2011 ponad 350 książek z całą pewnością będą-

47 HIM, DS, 100_Schmid.

48 Biblioteka Gdańska PAN, Akc, nr 4405-2002.

49 „Marienburger Zeitung”, 12, 1971, Nr. 285, s. 2: „Der deutsche Büchermarkt ist völlig ausgepumpt durch die vielen Luftangriffe, und ich sitze geistig hier wie Robinson auf seiner Insel”.

50 Sieradzan 2011, s. 105-109.

51 „Marienburger Zeitung”, 12, 1971, Nr. 285, s. 2. 
cych częścią jego bogatej biblioteki liczącej ok. trzy tysiące woluminów. Ponad wszelką wątpliwość ustalono, że były one jego własnością na podstawie zamieszczonych ekslibrisów, superekslibrisów, autografów, notatek ze źródeł archiwalnych oraz różnorodnych załączników. W skład zbioru wchodziły ponadto książki odziedziczone po ojcu (ok. 700 woluminów) oraz po wuju - Erneście von der Oelsnitz. Cały ten zasób podzielił w znacznym stopniu los zniszczonego Malborka i uległ częściowemu spaleniu, rozproszeniu lub rozgrabieniu. Ocalała w bibliotekach polskich jego część zaczęła służyć historykom polskim jako źródło poznania przeszłości ziem Polski Północnej i jej tak bogatego i złożonego dziedzictwa kulturowego. Częścią tego zbioru były tzw. Pommeranica i Prussica, czyli źródła, czasopisma i monografie, dotyczące również części obecnego województwa kujawsko-pomorskiego. Zapewne niezamierzoną zasługą Bernharda Schmida był fakt, że po wojnie część jego zbioru służyła historykom i historykom sztuki z Uniwersytetu Mikołaja Kopernika, którzy założyli w Toruniu szkołę historyczną, badającą dzieje państwa zakonu krzyżackiego w Prusach i historię Prus. Warto tu wspomnieć prof. Karola Górskiego, który jako pierwszy z tego, liczącego w Toruniu ok. 400 woluminu zbioru, czerpał wiele cennych materiałów ${ }^{52}$. Również niniejszy tekst nie powstałby bez pozostawionych przez Bernharda książek, dokumentów osobistych i korespondencji.

Reasumując można stwierdzić, że zasługi Bernharda Schmida dla dawnych ziem Prus Zachodnich, a tym samym również dla obecnych jej części, wchodzących w granice województwa kujawsko-pomorskiego - w szczególności zaś dla ziemi chełmińskiej - są ogromne i wielowątkowe. Poświęcił tej działalności około dwadzieścia pięć lat, czego efektem są realizacje konserwatorskie, sprawozdania oraz prace naukowe. Przez długi czas, jako konserwator prowincji był praktycznie jedyną osobą odpowiedzialną za tak znaczny obszar geograficzny obdarzony przez wieki licznymi zabytkami, których stan wymagał podjęcia prac konserwatorskich przez lokalne służby budowlane. Dobrze rozwinięta do 1920 roku sieć kolejowa umożliwiała Bernhardowi Schmidowi na dotarcie do wielu miejsc i przeprowadzanie nadzoru nad wykonywanymi pracami. Nie leży w kompetencji autora tego opracowania dokonanie całościowej oceny tych działań, ale można wstępnie uznać, że trudno czynić konserwatorowi zachodnio-pruskiemu jakieś większe zarzuty. Szkoda tylko, że nie zachowała się dokumentacja dokonanych prac, gdyż sprawozdania roczne zawierają niewiele fotografii.

Warto też podkreślić wagę księgozbioru zgromadzonego przez lata i pozostawionego przez Bernharda Schmida w Malborku. To dzięki niemu mogło powstać wiele prac naukowych polskich badaczy historii, historii sztuki oraz konserwacji zabytków.

52 BUMK, Zbiory Specjalne, b. sygn., znak akcesji D/117/2006. 
Wiesław Sieradzan

Faculty of History, Nicolaus Copernicus University in Toruń

\section{The services of Bernhard Schmid (1872-1947) to the region of Chełmno (Kulmerland)}

Polish and German literature dedicated to Berhard Schmid, a brilliant figure in the history of German conservation of monuments in the first half of the $20^{\text {th }}$ century, lacks a thorough description of his diverse actives in the region of what used to be the southern part of Western Prussia. This article is an attempt to answer the question whether the modern Kuyavian-Pomeranian region, especially what was once the Torun voivodeship, was an important area of academic and conservation work of the last monument conservator of Malbork, Berhard Schmid. If so, what were his services to the region and how did he contribute to the work on the recording and conservation of region's historical monuments. The author of the article presents a biographical note of Schmid and discusses his activities, as well as his family connections to the current Kuyavian-Pomeranian region. Despite being born in distant Saxony-Anhalt, Schmid's family was originally from Pomerania and Prussia. During Schmid's lifetime his family connections to Grudziądz, Chełmno, Toruń, Krusin and Bydgoszcz came to light. The author of the article analyses the impressive academic achievements of Schmid in the context of the Kuyavian-Pomeranian region. Many of Schmid's articles and reports concern conservation works in Torun, Bierzgłowo Castle and Grudziądz; especially regarding his participation in the securing and conservation of the Grudziądz Altar. In the next part of the article, the text lists the works carried out in the southern region of this province until the end of World War I, that were supervised by Bernhard in his capacity as monument conservator of Western Prussia. He focused particularly on the conservation of stained glass in the churches of Torun, the restoration of the refectory of the castle in Bierzgłowo, and the restoration of the altar of St. Wolfgang in the church of St. John the Baptist and St John the Evangelist in Torun, the church of St Catherine in Brodnica, the castle in Świecie on the Vistula, and in Papowo Toruńskie. Schmid was also extensively involved in the conservation of historical, movable artifacts in Grudziądz. He even formed the archive of monuments (Denkmalarchiv), connected with his office, which served the needs of ongoing conservation works. After World War II a section of his highly valuable private library, compiled during more than 50 years of deliberate collecting, was secured in Polish museums and libraries.

The author concludes that the services of Bernhard Schmid to the historical lands of Western Prussia, and thus also to parts of modern Kuyavian-Pomeranian Voivodeship are immense and diverse. His academic and conservation achievements reflect the fact that they are the result of around 25 years of work. 
